\title{
Питання психології
}

УДК 159.9:316.77(043.3)

DOI: $10.33099 / 2617-6858-20-54-1-221-226$

Якимчук Б. А., кандидат психологічних наук, дочент,

Уманський держсавний педагогічний університет імені Павла Тичини https://orcid.org/0000-0002-3303-6478

Рижкова Н. В., Військовий інститут КНУ ім. Тараса Шевченка https://orcid.org/0000-0002-6408-355X

\section{ПОТЕНЦАЛ САМОАКТУАЛІЗАЦІ ОСОБИСТОСТІ ЯК ЧИННИК ЇЇ ЕМОЦЙНОГО ВИГОРЯННЯ}

\begin{abstract}
У статті подано методологічні та теоретичні підходи до вивчення та визначення проблеми емочіонального вигорання. Досліджено вплив професії на особистість. Здійснено операціоналізацію поняття. Визначено чинники формування феномена емоційного вигорання особистості.
\end{abstract}

Ключові слова: емочійне вигорання; професія; особистість; феномен; чинник.

Постановка проблеми. Дія численних емоціогенних чинників, як об'єктивних, так і суб'єктивних, що викликають наростаюче почуття незадоволеності, погіршення самопочуття і настрою, акумуляцію втоми, зниження фізіологічних показників, що характеризують напруженість роботи, веде до професійних криз, виснаження i вигоряння особистості. Результатом цих процесів $€$ зниження ефективності професійної діяльності фахівців, вони перестають справлятися зі своїми обов'язками, втрачають творчий настрій щодо предмета та продукту своєї праці, деформують свої професійні відносини, ролі і комунікації (Є.Ф. Зеер, Н.В. Кузьміна, А.К. Маркова, Л.М. Мітіна, А.О. Реан, О.О.Рукавишников та ін.).

Проблема профілактики та психокорекції емоційного вигорання $\epsilon$ актуальною i вимагає здійснення комплексних превентивних i ситуативних заходів. Багато авторів констатують відсутність єдиної точки зору у розумінні цього психічного феномену, недостатню дослідженість причин і механізмів виникнення емоційного вигорання. I 3 теоретичної, і 3 практичної точки зору важливим $\epsilon$ і питання про роль зовнішніх $\mathrm{i}$ внугрішніх чинників у формуванні та розвитку феномена емоційного вигорання. (О.Я.Чебикін, С.Ф. Зеер, В.С. Орел, Т.В. Форманюк, G.Freudenberg, E.Gincberg, D.Super, Chr. Maslach, A.Pines, B.Aronson, SE Jackson). Між тим дослідження цього феномена сприяє більш поглибленому розумінню вікової динаміки та уточненню критеріїв його оцінки, що $\epsilon$ маркерами настання вікових та професійних криз [1].
Особливий інтерес в аспекті подолання вигорання представляє процес самоактуалізації особистості, який одні автори розглядають як системоутворюючий особистісний ресурс подолання вигорання, а інші - як чинник резистентності до вигоряння (J.R. Malanowski, P.H. Wood та ін.). Однак до сих пір недостатньо вивченою залишається роль самоактуалізації та окремих iii складових у регуляції професійного вигорання особистості протягом тривалого періоду, немає однозначної відповіді на питання про взаємовплив вигоряння, стресу і втоми, не визначено, які цінності особистості та особливості самоактуалізації сприяють або перешкоджають розвитку вигоряння.

Аналіз останніх досліджень i публікацій. Як зазначає С.О. Налічаева, емоційне вигорання, стрес i втома $\epsilon$ самостійними феноменами, причини та чинники їхнього виникнення мають схожість і відмінність, і на окремих етапах розвитку стрес і втома вносять свій внесок у формування окремих фаз та етапів розвитку емоційного вигорання i вони можуть взаємно доповнювати і посилювати свої прояви [2].

Як зазначає С.Л. Рубінштейн, будь-які зовнішні чинники діяльності впливають на особистість через призму внутрішніх умов [3]. Серед внутрішніх детермінант вигорання розглядають ціннісно-смислові особливості особистості (Л.Г. Дикая та ін.), емоційну спрямованість особистості, зміни у сфері емоційних станів і відносин фахівця (О.П.Саннікова та ін.), особливості ставлення до себе та інших (В.С. Орел), особливості професійної мотивації (Л.В. 


\section{Питання психології}

Занков, С.Г. Москвічев). Як зовнішні детермінанти вигорання розглядають умови праці (Н.С. Водоп'янова, О.С. Старченкова), моральну і матеріальну стимуляцію (А.А. Martinez та ін.), ставлення суспільства та ін. Через це важливим $є$ підхід до дослідження вигоряння як сістемномого явища, що відображає взаємодію зовнішніх чинників, особливостей професійної діяльності та індивідуально-психологічних особливостей самого суб'єкта праці.

У більшості праць вигорання розглядається як стан фізичного, психічного виснаження у фахівців соціономічних професій (H.Bredley, H.Freudenberger, C.Maslach), як стресова реакція (Н.Є. Водоп'янова, C.Cherniss), інші автори не зводять вигоряння ні до стомлення, ні до стресу, а розглядають його як екзистенційне явище (І.О. Куваєва), як «вигорання душі» (Л.О. Китаєв-Смик).

Мета статті - проаналізувати теоретико-методологічні підходи до вивчення феномену емоційного вигорання особистості у контексті іiі можливостей до самоактуалізації.

Методи дослідження - аналіз, узагальнення, порівняння, систематизація наукових джерел із проблеми дослідження.

Виклад основного матеріалу. При вивченні впливу професії на особистість необхідно проаналізувати підходи до розуміння взаємодії особистості і професії. Так, представники одного підходу вважають, що особистість відбирається професією. У цьому підході увагу дослідників сконцентровано на результативній стороні розвитку особистості професіонала (Ф.Парсон, Дж.Холланд, Е.Роу). Інший підхід до взаємодії особистості i професії побудований на припущенні про те, що професія обирається, виходячи із наявності певних якостей та установок особистості, але водночас із цим кожна професія накладає специфічний відбиток на психічний вигляд людини. Через це професійне становлення особистості розглядається як процес самоактуалізації (E.Gincberg, D.Super, Chr. Maslach, E.O. Клімов, Т.В. Кудрявцев).

Емоційне вигоряння представлено як один із проявів професійної деформації, тобто 3 точки зору впливу професії на особистість (М.В. Агапова, Р.М. Грановська,
А.К.Маркова, О.М. Нікіфоров, С.Г. Геллерштейн, Ю.П. Поваренков). Процес професійного становлення $\epsilon$ однією із найбільш важливих складових у загальній життєдіяльності людини, саме у професійній діяльності найбільш інтенсивно відбувається зміна особистості. У працях Є.О. Клімова, В.С. Орла, Л.П. Урванцева, Т.В. Кудрявцева, О.В. Сухарєва та інших переконливо доведено, що ці зміни торкаються усіх сфер особистості i проявляються на різних рівнях її організації.

Уперше проблема емоційного вигоряння у психології з'явилася у США у 70-х роках минулого століття, i не як дослідницький конструкт, а як соціальна проблема. У контексті досліджень проблеми негативного впливу професійної діяльності на особистість Freudenberger в 1974 році ввів спеціальний термін «burnout». Це поняття було розкрито нимм як синдром, що містить симптоми загальної фізичної стомленості і розчарування у професії альтруїстичного змісту. Chr. Maslach, S.E. Jackson додали також симптоми емоційної виснаженості, деперсоналізації і зниження загальної працездатності.

На сьогоднішній день найбільш часто вживаним $\epsilon$ визначення вигоряння, дане Chr.Maslach i S.E. Jackson y 1986, де вигоряння представлено як синдром емоційного виснаження, деперсоналізації і зменшення особистісних досягнень, що виникає у фахівців, які працюють із людьми. Pines i Aronson описують вигорання як стан фізичного, емоційного i психічного виснаження, викликаний тривалим включенням у ситуацію, яка висуває високі вимоги до емоційної сфери. Brill вважає, що вигоряння має два специфічних симптома дисфоричні симптоми і зниження досягнень на роботі. Вигорання розглядається цими авторами як стан, пов'язаний із роботою, що виникає у «нормальних» індивідів, які не страждають психопатологією i раніше функціонували на адекватному рівні.

Емоційне вигоряння як процес визначає Cherniss, він вводить новий елемент етіології вигоряння - індивідуальний спосіб подолання стресу. Як процес зростаючого розчарування описали вигоряння Edelwich, Brodsky, Etzion. Більшість авторів, розглядаючи процес вигоряння, відзначають, що він починається із напруги, яке $\epsilon$ результатом суперечності між 


\section{Питання психології}

очікуваннями, намірами, бажаннями та ідеалами особистості і вимогами суворої повсякденної реальності (Armstrong, Barner, Beck, Gargiulo, Forney, Wiggers, Kelli, Tomhave, Rubington, Farber, Harrison, Maslash, Pines).

У науковій літературі також можна зустріти дані про «згоряння» (як синонім), існуючому серед людей соціономічних професій. У цьому випадку «згорання» визначається через симптоми фізичної втоми та емоційної виснаженості у відповідь на дії стрес-чинника виробничого середовища, пов'язаного iз міжособистісними відносинами. В останні роки поняття «вигорання» стало з'являтися усе частіше [4-11]. Процес вигоряння виникає на окремих періодах професійного розвитку i в більшості випадків розглядається як «хвороба спілкування» (Л.О. Китаєв-Смик).

Проаналізувавши поняття «вигорання», В.В. Козлов зробив висновки висновки, що воно змістовно збігається із поняттям «духовна криза» [1]. Саме деформація або загроза деформації як фруструючий чинник для ядерних компонентів Его і близьких до них за ціннісною значущістю компонентів $€$ основною причиною психодуховної кризи. Симптоми, супутні процесу емоційного вигорання, диференціюються на афективні, когнітивні, фізичні, поведінкові та мотиваційні i проявляються на індивідуальному, міжособистісному та організаційному рівнях.

Операціоналізація

феномена «емоційного вигорання» дозволяє розглядати його як стійке, прогресуюче, негативно забарвлене психологічне явище, що починається 3 психоемоційного напруження i приводить до виснаження, розвитку дисфункціональних установок i поведінки на роботі, зниженням або втратою професійної мотивації, що виявляється у професійній діяльності. Щодо чинників формування феномену «емоційного вигорання», то у зарубіжній психології сформувалися індивідуальний, інтерперсональний та організаційний підходи (H.Freudenberger, Richelson; Edelwich, Brodsky, Meier; Hobfoll, Freedy; Hobfoll, Shirom; Fischer; A.Pines, Harrison; Chr.Maslach; Buunk, W.Schaufeli; Arlie Hochschild; C.Cherniss, Winnubst, RT
Golembiewski, J.De Jonge, Ф.Сторлі, П.Коста, Р.Макграє).

Процес самоактуалізації можна розглядати як внутрішню основу для самореалізації особистості, бо самореалізація $\epsilon$ процесом і результатом втілення себе, власних особистісних потенцій у діяльності та іï продукті (А.Маслоу, К.Роджерс, К.Г. Юнг, Р.Ассоджіолі, С.Гроф). Порушення в процесі самоактуалізації безпосередньо пов'язані із проблемою емоційного вигорання, оскільки вони змінюють систему цілей, смислів, цінностей особистості, впливають на формування особистісних якостей, визначають реакції суб'єкта на зовнішні чинники. У контексті співвідношення самореалізації i самоактуалізації представляють інтерес сентенції Д.О. Леонтьєва, який розглядає три рівня самореалізації особистості, теорія транскоммунікаціi В.I. Кабрина, В.А. Петровского про принцип єдності свідомості і діяльності, І.Б. Дерманова і Л.А. Коростильова про два полюси самореалізації, Н.Ю.Хрящової про зв'язок самореалізації та творчості, теорія психологічних систем В.С. Клочко та Є.В.Галажинського, а також В.В. Козлова про самоактуалізацію як «ресурсний стан свідомості». У дослідженнях В.А. Адольфа, І.Ф. Демидової, Л.М. Захарова, Є.І. Ісаєва, Н.В.Кузьміної, А.К. Маркової професійна компетентність базується на певних основах, до яких входить і самореалізація особистості.

На повноцінно функціонуючу особистість, що самоактуалізується, самореалізується несприятливі середовищні чинники (будь-то соціальні, організаційні, діяльні чи інші не можуть справити критичного впливу, оскільки вона наділена певним «запасом міцності», на основі якого можна перетворити стресор на чинник самодетермінації. Особистість, яка само актуалізується, володіє «протиотрутою» по відношенню до вигоряння саме за рахунок високої активності щодо осмислення свого місця і ролі у життєвій ситуації інших людей, усвідомлення власної місії та готовності «платити» за самоідентичність і самореалізацію. Людина ж, яка не самореалізуюється, зі слабкою тенденцією до самоактуалізації, схильна до опору, конфронтації із несприятливими 


\section{Питання психології}

середовищнними чинниками i усією професійною ситуацією у цілому, вона перестає відчувати задоволення від роботи, не може ставитися творчо до своїх професійних обов'язків, відчуває себе перевантаженою проблемами інших людей, що у сукупності призводить до відчуження від предмета і продукту своєї праці. Таким чином, одним із найважливіших чинників формування емоційного вигорання $\epsilon$ комплекс особливостей самоактуалізації.

Висновки та перспективи подальших досліджень. Таким чином, емоційне вигорання - це стійке, прогресуюче, негативно забарвлене психологічне явище, що починається із психоемоційного напруження і приводить до виснаження, розвитку дисфункціональних установок i поведінки на роботі, зниження або втрати професійної мотивації, що виявляється у професійній діяльності. Воно являє собою цілісний симптомокомплекс, дія якого охоплює усі основні структурні рівні особистості: соціально-психологічний, що відображає зміну міжособистісних відносин; особистісний - що відображає зміну особистісних рис; мотиваційний - що відображає якісну i змістовну зміну мотивації; а також регулятивноситуаційний, що відображає зміну станів та емоційних відносин.

При емоційному вигорянні змінюється система смислів і цінностей особистості, психоемоційні витрати починають перевищувати особистісно значущий очікуваний результат, тому змінюється ставлення суб'єкта до своїх професійних обов'язків, відбувається відчуження від предмета і продукту своєї праці, які по суті $\epsilon$ соціально-психологічними. Тобто, чим менше виражена самоактуалізація особистості, тим більш імовірним, реальним i глибшим $\epsilon$ емоційне вигоряння. Іншими словами, чим менш виражені прояви емоційного вигорання на кожній стадії, тим більше вираженою $є$ самоактуалізація особистості. Емоційне вигорання і рівень невротизації особистості фахівця позитивно корелюють. Фахівець із хорошим контролем над власною емоційною сферою, цілеспрямований, вольовий і рішучий має меншу ймовірність емоційного вигорання. У тому випадку, коли емоційне вигорання виходить за межі професійної діяльності, рекомендується психокорекція та психотерапія, звернення за психологічною допомогою.

Перспективами подальших досліджень у обраному напрямку можна вважати вивчення ризиків професійної діяльності фахівців, які можуть провокувати появу i розвиток у них синдрому емоційного вигорання, удосконалення психологічного інструментарію превентивної діагностики i психотехнологій попередження професійних стресів, розробку системи психологічного моніторингу їхнього психічного i душевного здоров'я, психопрофілактику проявів синдрому емоційного вигоряння на різних етапах їхньої професіоналізації.

\section{Список використаних джерел}

1. Козлов В.В. Психология кризиса: монографія. М.: Институт консультирования и системных решений. 2014. 528 с.

2. Наличаева С.А. Самоактуализационный потенциал личности как детерминанта профессионального выгорания педагогов: дисс. канд. психол. наук. М., 2011. 238 с.

3. Рубинштейн С.Л. Проблемы общей психологии. М., 1973. 339 с.

4. Андрух I.В. Психологічні умови запобігання емоційного вигорання оперативними співробітниками Служби безпеки України: дис. канд. психол. наук. Національна академія Державної прикордонної служби України імені Богдана Хмельницького, Хмельницький, 2016. 196 с.

5. Булатевич Н.М. Синдром емоційного вигоряння вчителя: дис на здобуття наук. ступеня канд. психол. наук. Київський національний ун-т ім. Тараса Шевченка. К., 2004. 19 с.

6. Грицук О.В. Психологічні особливості динаміки емоційного вигорання вчителів: автореф. дис. канд. психол. наук Харків, 2010. 23 с.

7. Жогно Ю.П. Психологічні особливості емоційного вигорання педагогів: автореф. дис. канд. психол. наук. Одеса, 2009. 23 с.

8. Леженіна Л.М. Психологічні чинники емоційного вигоряння слідчих Служби безпеки України: дис. канд. психол. наук. Харківський національний педагогічний університет ім. Г.С. Сковороди. Харків, 2009. 186 с. 


\section{Питання психології}

9. Малишева К.О. Синдром емоційного вигоряння психолога-консультанта: психологічні чинники, профілактика та корекція: дис. канд. психол. наук. Київський національний ун-т ім. Тараса Шевченка. К., 2003. 16 с.

10. Міщенко М.С. Психологічні чинники запобігання синдрому емоційного вигорання у майбутніх практичних психологів: дис. канд. психол. н. Київський національний університет імені Тараса Шевченка МОН України. К., 2015. 156 с.

11. Чепелєва Н.О. Психологічні особливості емоційного вигорання викладачів вищих навчальних закладів: автореф. дис. канд. психол. наук. Одеса, 2010. 20 с.

\section{References}

1. Kozlov V.V. Psihologija krizisa [Psychology of crisis]: monografija. M.: Institut konsul'tirovanija i sistemnyh reshenij. 2014. 528 s. (in Russian)

2. Nalichaeva S.A. Samoaktualizacionnyj potencial lichnosti kak determinanta professional'nogo vygoranija pedagogov [Self-actualizing potential of a personality as a determinant of professional burnout of teachers]: diss. kand. psihol. nauk. M., 2011. 238 s. (in Russian) Russian)

3. Rubinshtejn C.L. Problemy obshhej pcixologii [Problems of general psychology]. M., 1973. 339 c. (in

4. Andrux I.V. Pcyxologichni umovy zapobigannja emocijnogo vygorannja operatyvnymy cpivrobitnykamy Cluzhby bezpeky Ukrai'ny [Psychological conditions for emotional burnout by operative employees Security Service of Ukraine]: dys. kand. psyhol. nauk. Nacional'na akademija Derzhavnoi' prykordonnoi' cluzhby Ukrai'ny imeni Bogdana Xmel'nyc'kogo, Xmel'nyc'kyj, 2016. 196 s. (in Ukranian)

5. Bulatevych N.M. Cyndrom emocijnogo vygorannja vchytelja [Teacher's emotional burnout syndrome]: dyc na zdobuttja nauk. stupenja kand. pcyxol. nauk. Kyi'vc'kyj nacional'nyj un-t im. Taraca Shevchenka. K., 2004. 19 c. (in Ukranian)

6. Grycuk O.V. Psyhologichni osoblyvosti dynamiky emocijnogo vygorannja vchyteliv [Psychological features of the dynamics of emotional burnout of teachers]: avtoref. dys. kand. psyhol. nauk Harkiv, 2010. 23 s. (in Ukranian)

7. Zhogno Ju.P. Psyhologichni osoblyvosti emocijnogo vygorannja pedagogiv [Psychological features of emotional burnout of teachers]: avtoref. dys. kand. psyhol. nauk. Odesa, 2009. 23 s. (in Ukranian)

8. Lezhenina L.M. Pcyxologichni chynnyky emocijnogo vygorjannja clidchyx Cluzhby bezpeky Ukrai'ny [Psychological factors of emotional burning of investigators Security Servic of Ukraine]: dyc. kand. psyhol. nauk. Xarkivc'kyj nacional'nyj pedagogichnyj univercytet im. G.C. Ckovorody. Harkiv, 2009. 186 c. (in Ukranian)

9. Malysheva K.O. Cyndrom emocijnogo vygorjannja pcyxologa-koncul'tanta: pcyxologichni chynnyky, profilaktyka ta korekcija [Emotional burnout syndrome of psychologist-consultant: psychologic factors, prophylaxis and correction]: dys. kand. pcyxol. nauk. Kyi'vc'kyj nacional'nyj un-t im. Taraca Shevchenka. K., 2003. 16 c. (in Ukranian)

10. Mishhenko M.S. Psyhologichni chynnyky zapobigannja syndromu emocijnogo vygorannja u majbutnih praktychnyh psyhologiv [Psychological factors for the prevention of emotional burnout syndrome in future practical psychologists]: dys. kand. psyhol. n. Kyi'vs'kyj nacional'nyj universytet imeni Tarasa Shevchenka MON Ukrai'ny. K., 2015. 156 s. (in Ukranian)

11. Chepeljeva N.O. Psyhologichni osoblyvosti emocijnogo vygorannja vykladachiv vyshhyh navchal'nyh zakladiv [Psychological peculiarities of emotional burnout of higher education teachers]: avtoref. dys. kand. psyhol. nauk. Odesa, 2010. 20 s. (in Ukranian)

\section{Резюме \\ Якимчук Б. А., кандидат психологічних наук, доцент, Уманський державний педагогічний університет імені Павла Тичини Рижккова Н. В., Військовий інститут КНУ ім. Тараса Шевченка ПОТЕНЦИАЛ САМОАКТУАЛИЗАЦИИ ЛИЧНОСТИ КАК ФАКТОР ЕЕ ЕМОЦИОНАЛЬНОГО ВЫГОРАНИЯ \\ В статье излагаются методологические и теоретические подходы к изучению и определению проблемы эмочионального выгорания. Исследовано влияние профессии на личность. Осуществлена операционализация понятия. Определены факторы формирования феномена эмоционального} выгорания личности.

Ключевые слова: эмочиональное выгорание; профессия; личность; феномен; фактор. 


\section{Питання психології}

\section{Summary}

Yakimchuk B., associate Professor in psychological sciences, Uman Pavlo Tichina State Pedagogical University Ryzhkova N., Postgraduate Student of the Military Institute of Taras Shevchenko National University of Kyiv

\section{SELF-ACTUALIZING POTENTIAL AS A FACTOR OF PERSONALITY EMOTIONAL BURNOUT}

Introduction. The problem of prevention and psychocorrection of emotional burnout is urgent and requires comprehensive preventive and situational measures. Many authors state the absence of a single point of view in understanding this psychic phenomenon, the lack of research into the causes and mechanisms of the occurrence of emotional burnout. From a theoretical and practical point of view, the question of the role of external and internal factors in the formation and development of the phenomenon of emotional burnout is also important.

Purpose. The analysis of theoretical and methodological approaches to the study of the phenomenon of emotional burnout of a personality in the context of it's possibilities for self-actualization.

Methods. Analysis, generalizations, comparisons, systematization of science sources with problems of research.

Originality. The symptoms and factors of the occurrence of personality burnout are summarized and classified. The psychological structure of emotional burnout and its relationship with the features of selfactualization of a person are considered. The determinism of the occurrence of emotional burnout was revealed by the lack of the possibility of realizing the processes of personal self-actualizationt. The study allows us to expand our understanding of the possible causes of emotional burnout as a result of violations of the processes of self-actualization of a personality. Practical significance consists in the possibility of developing recommendations for the prevention of emotional burnout and its psychocorrection programs according to the phases and depth of emotional burnout and violation of self-actualization processes.

Conclusion. Emotional burnout is a persistent, progressive, negatively colored psychological phenomenon that begins with psycho-emotional stress and leads to the exhaustion, development of dysfunctional attitudes and behavior at work, the decline or loss of professional motivation manifested in professional activity. It is a holistic symptom complex, the action of which covers all the basic structural levels of personality: social and psychological; motivational; as well as regulatory and situational. A specialist with good control over their own emotional sphere, focused, strong-willed and determined is less likely to be emotionally burned out. In the case where emotional burnout goes beyond professional activity, psychocorrection and psychotherapy, seeking psychological help are recommended.

Key words: emotional burnout; profession; personality; phenomenon; factor. 